\title{
Where Power Meets Knowledge
}

\section{The Case of Latin American Studies in Poland}

\begin{abstract}
The new Law on Higher Education and Science, referred to as the "Constitution for Science" or the "Law 2.0," has thoroughly reshaped research activities and academic education in Poland, and Latin American Studies - which gained a well-established position since the transformation of the 1980s and 1990s - is no exception. However, it would appear that the introduced changes may have a negative, rather than positive impact. The following article sets out to outline the current situation of Latin American Studies in Poland in the context of the relations between science and politics under the circumstances of the new legislation.
\end{abstract}

Key words: Latin American Studies in Poland; scientific journals; Constitution for Science; C.P. Snow

\section{Science vs. Politics}

The relationship between politics, and more precisely the government, and science is tight. This comes as a consequence of the financial support that the state grants for the development and practical application of research, as well as for education. At the same time, we, the researchers, scientists, and teachers would prefer to conduct our activities free from any political influence, i.e. free from any pressure on the part of those currently in power. This is also stipulated in the Constitution of the Republic of Poland. However, as Jacek Sobczak puts it in his 2008 article Wolność badań naukowych [Freedom of scientific research]:

Among the catalogue of human rights and freedoms formulated in the Constitution of the Republic of Poland of 1997, the freedom of scientific research is rarely mentioned. Along with the freedom of artistic creation, the freedom of access to cultural goods, the freedom of teaching, and the freedom of publication of scientific research results, it is mentioned in the Article 73, Chapter II of the Constitution The Freedoms, Rights and Obligations Of 
Persons And Citizens, as a part of economic, cultural, and social rights. From the point of view of the systematics of the Constitution, this solution seems perfectly fine. However, it is impossible to overlook that the lawmaker does seem to be far more concerned with the freedom of press and other means of social communication which, listed in Article 14 of Chapter I of the Constitution, has become one of the constitutional principles (Sobczak 9).

The fact that the entity that determines the supply of knowledge and explanations regarding the changes taking place in the reality that surrounds both us and the politicians is of "lesser concern" may prove unsettling. It does not, however, imply underestimation of the value of science as such. Such lesser concern may reflect the conviction about an inalienable control over and a possibility of shaping research and educational activities. Nonetheless, Jacek Sobczak (2008) looks at this from a different perspective, and tends to point out the threats that stem first and foremost from the excessive freedom of research:

The basic human characteristics include unquenchable curiosity and untamed ambition. They propel the scholars to take on new challenges against all odds and all restrictions and risks. The outcomes of such pursuits are impossible to predict. It can be feared, however, they may eventually lead to the extinction of humankind. A spectre of such calamity and its prophecy have accompanied mankind virtually from times immemorial. We may only hope that it will not come true in the nearest future (Sobczak 43).

Simultaneously, Sobczak indicates that we should not focus exclusively on the most basic discussions on academic freedom - as is the case of the use of the atomic bomb-and he highlights the need of addressing "softer" issues, so to say, which take into consideration the world view, the attitude towards the other, and the transposing and correlation of political and strategic interests to science and research.

These issues were considered by Charles Percy Snow, known for his Two Cultures essay in the book Science and Government, where he analysed the irresponsibility among the power holders (politicians, technocrats) who, outnumbered by researchers/scientists and the general society as such, make decisions regarding science (a field they do not know or understand), which very often affect the society in a negative manner, as history has shown. Rather than criticizing it, Snow (1961) tries to understand and explain it, indicating dissimilar objectives and perspectives of science and politics. According to him, politicians view the world and its future in the context of a few years (term of office), while the scientific horizon is much larger, if not infinite.

It is in the making of weapons of absolute destruction that you can see my central theme at its sharpest and most dramatic, or most melodramatic if you like. But the same reflections would apply to whole assembly of decisions which are not designed to do harm. For example, some of the most important choices about a nation's physical health are made, or not made, by a handful of men, in secret, and, again in legal form, by men who normally are not able to comprehend the arguments in depth. This phenomenon of the modern world is, as I say, bizarre. We have got used to it... In the West, we have not been very good at looking at this singularity with fresh and candid eyes. We are too apt to delude ourselves with phrases like "the free world" or "the freedom of science"... Such phrases only obscure the truth... (Snow 1-2) 


\section{Constitution for Science}

I personally believe that the thesis proposed by C.P. Snow, a controversial intellectual and a distinguished scientist, serves as a favourable starting point for considering the transformation and changes that have taken place in the Polish Latin American Studies in recent years. Similarly to other fields of research, it has been affected by the introduction of the Law on Higher Education and Science, which in spite of the government's declarations and flexible provisions, results in a centralisation of decision-making processes in regard to science and higher education in Poland, introduces categorisation of research (scientific and didactic) - and thus a strong competition between them - strengthens the paradigm of disciplinarity in science, subjects the evaluation of people's work to the tools of bibliometrics based on Anglo-Saxon solutions, and solidifies the relationship with enterprises and industry, both in terms of financing of science and the demand-and-supply principle. One could conclude that as a result of the reform, science in Poland will be treated as a product subject to quantifiable assessment, tasked with delivering tangible profits. Therefore, there can be no doubt that in competing for the highest scientific category, the universities will introduce systems of assessment and rewards of their staff that will replicate the principles set in the legislation. The rule: "publish highly scored papers or you shall have no value as an employee will be introduced" (Osiński). Simultaneously, the new Law, with its emphasis on parametric assessment of disciplines - rather than departments - weakens the commitment to mutli- and interdisciplinary projects, both in research and publishing. Funding, in the light of the new Law, will go to the best representatives of a given discipline or specific disciplines within universities. These changes are most likely to result in a situation where launching new courses at a given university will depend on the strength of specific disciplines.

This, unfortunately, puts Latin American Studies at a disadvantage. It can lead to abandoning inter- and multidisciplinary research and discourage from undertaking other initiatives of such type, i.e. publishing projects. In a longer run, this may also affect the curricula and impoverish Polish scientific activities dedicated to Latin America, especially in the field of social sciences and humanities.

I believe this to be a crucial issue for Latin American Studies - taking into account that their foundations were laid in the context of a political dispute between the United Kingdom, the United States of America, and France over the influence in Latin America, also in the field of science, since the countries in question represent quite different approaches to the institutional landscape of research and higher education. In fact, the very name of the region is a product of this clash of visions and interests.

\section{Latin American Studies in Poland: current status and forecasts}

There is little doubt that research on Latin America in Poland is in the course of transformation. Currently Latin American Studies are becoming increasingly dispersed in comparison to the previous concentration in several centres, dominated 
by Warsaw, and are becoming increasingly diversified in terms of subjects and disciplines. This process gained momentum after the closure of the Centre for LatinAmerican Studies (CESLA) at the University of Warsaw and subsequent incorporation of its components (library, part of faculty, and journals) into the American Studies Center (ASC) at the same university.

Throughout the last decade, the number of scholars on Latin America has not decreased substantially and maintains a steady level of ca. 180 persons, ${ }^{1}$ and apart from the highly active universities in Kraków (Jagiellonian University), Poznań (Adam Mickiewicz University), Łódź (University of Lodz), Lublin (Maria Skłodowska-Curie University), and Warsaw (University of Warsaw) that have a long-established tradition of Latin American research, new scientific groups have emerged, such as those in Bielsko-Biała (University of Bielsko-Biała), Wrocław (University of Wrocław), Opole (Opole University), Białystok (University of Białystok), or Torun (Nicolaus Copernicus University in Torun). Likewise, the number of new PhD and habilitation theses has not decreased in comparison to the previous decade (Dembicz and Doroszewicz), amounting to a total of no more than 20 per year. For instance, in 2013 ca. 10 doctoral theses and 3 habilitation proceedings were concluded successfully, while there were 7 and 4 , respectively, in $2017 .^{2}$

At the same time, two parallel trends in the development of Latin American Studies can be seen in Poland. On the one hand, there is a strengthening of the distinction between the Latin American Studies and those dedicated to the Americas and United States in particular. Thus, the Institute of Iberian and Ibero-American Studies of the University of Warsaw (and its Itinerarios review) functions as good as ever, and the same is true for the American Studies Center at the same university with the journal The New Americanists. On the other hand, there is a global trend to shift towards hemispherical studies (Western hemisphere) and complementing studies on the US with a Latin American component. The Polish case, especially at the University of Warsaw, seems to follow this Europe-wide trend, initiated at the beginning of the 21st century, in which a number of institutions carrying out research on Latin America lost their autonomy and were incorporated into a wider structure of studies within other disciplines, regional studies, on the Americas, or global studies. Such was the case of Latin American Studies in Vienna, Hamburg, and in some French centres. In the case of the Jagiellonian University, from the very beginning, the department of studies on Latin America has developed within the framework of the Faculty of Political Sciences and an institute dedicated to the studies of both Americas. It is currently the largest center of American Studies (including Latin America) in Poland, and its Americanist profile is highlighted in the scientific journal published in English and titled Ad Americam.

Certainly, this comes as a result of the internationalisation of science, which increasingly demands the use of the English language in teaching and in scientific communication (including publishing), the return to the paradigm of disciplinarity, and the application of a global approach in the research. In Poland, this is reflected in journals' shift from Polish to English and most importantly in adopting English as the primary language of communication. It also applies to teaching programmes

Own estimates, based on the data in the "Ludzie nauki" database.

2 Own estimates, based on the data in the "Ludzie nauki" database. 
of Master Degree courses. Currently, only two universities offer masters in Latin American Studies, the Institute of American Studies and Polish Diaspora at the Jagiellonian University in Cracow and the Instituto de Estudios Ibericos e Iberoamericanos at the University of Warsaw. The former emphasizes political science and interdisciplinarity, the latter humanities and culture.

In this context, a forecast may be made. We can surely indicate a threefold nature of the result of the changes that take place in Polish Latin American Studies, both negative and positive ones. First of all, there arise new opportunities for collaboration and exchange of ideas both with centres in the United States, which have been engaged in extensive and multidisciplinary studies on Latin America and the Caribbean since the 1940s, and with Asian universities, which offer a "fresh perspective" and a different approach. European and international funds create opportunities and thanks to these possibilities, large research projects dedicated to Nahuatl culture and language, Andean archeology, Cuban transformation, Mexican and Central American local societies are currently being developed. All of them are increasingly immersed in the comparative paradigm.

Unfortunately, as a side-effect of such a shift, the outreach of Polish scientific production is limited among the academia of Latin America and Spain, which often considers the use of Spanish as an expression of dissent against the alleged AngloSaxon domination in science and as an acknowledgement of the Latin American historical heritage.

The third implication of this process concerns the Polish context. I mean the fact of limiting the opportunities for young scholars to perfect their scientific skills in Polish, i.a. to disseminate Polish scientific vocabulary, which in a consequence, makes research results less accessible to the general public in Poland.

The above remarks stem from, inter alia, the observation of Polish journals dedicated to Latin American Studies. There have been profound changes in their situation in the last decade. Actas Latinoamericanas de Varsovia and Azja, Afryka, Ameryka Łacińska, both with a long-established tradition, have disappeared from the market. Others, such as Estudios Latinoamericanos, Revista del CESLA and Ameryka Łacińska, of multi- and transdisciplinary nature, struggle to be included in indexed journal databases and to obtain high scores, which in fact, is the matter of their survival. Meanwhile, scientific journals limited to single disciplines, such as Itinerarios or the recently-created Anuario Latinoamericanista - the former representing literature studies and linguistics, the latter dedicated to political science-are solidifying their positions. At the same time, there arises another interesting phenomenon: the incorporation of Latin American themes in journals dedicated mainly to North America so far. This is the case of this journal, Ad Americam, by the way.

In the case of Poland, the new standards imposed by the government and international institutions do not favour consolidation of the Latin American scholars' milieu. In a longer perspective, the absence of a scientific centre with a Latin American Studies profile and an independent curriculum is most likely to prove disadvantageous to the development of Latin American Studies in Poland. This is reflected, for instance, in the fact that no major conference or congress on Latin American Studies, such as FIEALC or CEISAL meetings, takes place in Poland, although smaller conferences and seminars, limited to single disciplines or issues, are organised, for example, Annual Latin American PTSL, Cracow Latin American Conferences (which 
have had five editions up until now), or Latin American scientific meetings in the UMCS Lublin University. These events gathered academics from different parts of the world. However, there is no single body to coordinate efforts towards a joint event that would make Polish Latin Americanism visible. Sadly, the public debate on Latin America also seems to confirm this lack of visibility, as exemplified by the sessions dedicated to Latin America organised by the Polish Sejm (Parliament), where experts and scholars from foreign centres are invited, while the members of Polish academia are not.

Hopefully, non-governmental associations, foundations, and societies, such as the dynamic Polish Association of Latin American Studies (PTSL), the Terra Brasilis foundation, Centro Latino in Cracow, or the Professor Andrzej Dembicz Foundation, may mitigate the side effects of the changes that are taking place. However, such bodies have limited financial means and restricted capabilities of creating curricula. Still, the new Law encourages inter-sectorial relations and collaboration.

Certainly, the transformation of Polish Latin American Studies requires further observation and analysis, not only as a mere documentation of Latin American Studies in Europe and in the world, but first and foremost in order to analyse the relationship and interactions between science and politics.

\section{References}

Dembicz, Katarzyna, and Wojciech Doroszewicz. "Latin American Studies in Poland in the Light of PhD and Habilitation Theses Written after 1980." The Nature and Culture of Latin America. Review of Polish Studies, Z. Mirek, A. Flakus, A. Krzanowski, A. Paulo, \& J. Wojtusiak (Eds.), W. Szafer Institute of Botany, Polish Academy of Science, 2010, pp. 355-361.

Levander, Caroline, and Robert Levine. Hemispheric American Studies. Rutgers UP, 2008.

Osiński, Zbigniew. "Badacze czy kwestorzy" Forum akademickie 04/2019, https:/ / prenumeruj.forumakademickie.pl/fa/2019/04/badacze-czy-kwestorzy/. Accessed 27 September 2019.

Sobczak, Jacek. „Wolność badań naukowych. Standardy europejskie a rzeczywistość polska.” Roczniki nauk społecznych Vol. XXXVI, z. 1. 2008, pp. 53-74.

Snow, Charles Percy. Science and Government, Harvard University Press, 1961. 